aspect may exhibit a greater abundance of species, though less well developed, from the continuous play of sporesand rain-upon the trunk.

Of north and south positions the same may be said, i.e. the south is sheltered from fierce, cold north winds, yet open to warm, rain-depositing winds. Again, once established, cryptogams flourish on the southern aspect best owing to its sunny character. North winds blow when spores are not so abundant, and the same applies to boisterous east winds, though these are short-lived.

Apart from wind dispersal of spores, vegetative reproduction tends to favour the same situations, south or east, for south-west winds bring moisture, and, when not laden with poisonous substances, are beneficial; but longcontinued wind tends to drive plants to the east side, and absence of sun from north to south.

The causes inducing birds to nest preferably on the eastern and southern sides of hedges (and trees, to some extent) are much the same, i.e. protection from wind and the greater safety of a leeward position and amount of sunlight; but in their case, also, there is light dispersal. There is a shadow on the leeward side of hedges for a great part of the day after the early dawn, and this enables birds safely to go in and out without being observed.

The western side presents fewer convenient nesting sites, the branches of hedges being generally bent over from west to east, as seen best on the west coast, affording a better arbour on the east. The south and east face early dawn longest, and this is the favourite season of the birds. At any rate, their song is richest between 4 and $8 \mathrm{a} . \mathrm{m}$. The north and west are open to bright sun but during the colder part of the day.

As to the actual distribution of nests, the same positions noticed by Lieut.-Colonel Tull Walsh are favoured by birds in Leicestershire, Shropshire, Surrey, amongst other counties, and seem to be more or less general. The need for studying cryptogamic distribution in relation to wind in connection with the extinction of plants led me to formulate the conclusions noted. It is interesting to observe that they are directly analogous to the position of birds' nests in hedges. Hence the parallel drawn.

A. R. HoRWOOD.

Leicester Corporation Museum, December 22.

\section{Studies in Polychæt Larvæ.}

MAY I make use of your columns to correct an error in my "Studies in Polychæt Larvæ" in a recent number of the Q.J.M.S.? The specimen there described as a young Odontosyllis sp. I have since found to be in reality a fully grown Exogone. I have been unable to identify it with any known species, but as dorsal natatory setæ are quite well known in specimens of Exogone of this size, the conclusions drawn from this specimen are of no value.

With regard to the last section of the same paper, it has lately come to my notice that de Saint-Joseph has shown Claparède and Mecznicow's so-called Spionid larva, in which there are no provisional setæ, to be the larva of the aberrant worm Saccocirrus, and not of one of the Spionidæ. There is, then, no known exception to the rule that free-swimming Spionid larvæ bear provisional setæ.

F. H. Gravely.

5 Silver Street, Wellingborough, December $27,1909$.

\section{Cross-fertilisation of Sweet-peas.}

I HAVE recently seen two further reiterations of the statement that the sweet-pea is invariably self-fertilised, a statement which I think is often based on an opinion of Charles Darwin's. It may therefore be worth while placing on record an observation made by $m e$ in 1907 , when examining daily and closely a large quantity of sweet-peas. While Apis mellifica failed entirely to open the flower, it was done perpetually by Megachile willughbiella, and there was not the least doubt about the cross-fertilisation being effectively brought about by this bee. The point has probably been noted before, but it is worth recording once more in view of the repetition of statements as to the self-fertilisation of sweet-peas.

No. 2097 , VOL. 82]

\section{A Supposed New Mineral.}

WhEN we wrote recently (NATURE, October 28, 1909) about a supposed new mineral from Co. Antrim, we were led to believe that the specimen we had received was from the basalt-our information, in fact, was that "a very big pocket of it " had been found in that rock, but the exact locality could not be ascertained at that time, the finder having left home.

We now hear that this gentleman cannot remember where he got the specimen. It certainly cannot be traced to the basalt, and as its composition is unlike that of any known mineral, it seems highly probable that the substance is an artificial product.

RICHARD J. MOSS.

Laboratory, Royal Dublin Society, HeNRY J. SEYMOUR.

December 23, 1909.

\section{THE HEART OF ANTARCTICA. ${ }^{1}$}

I MMEDIATELY after the arrival of the British Antarctic Expedition of 1907-9 in New Zealand the attempt was made in Nature (April I, I909, vol. Ixxx., p. I3o) to estimate its scientific results from the information received by cable. The full details now supplied show that the estimate then made in no way exaggerated the greatness of its achievements. The full story of the expedition, told in these most interesting and beautifully illustrated volumes, shows that its great success was due to careful and scientific foresight in equipment, to the determined and uttermost use of the equipment and staff, and to daring in the field, carried sometimes to the verge of recklessness, but saved from accidents by sound judgment and cool courage.

The main purpose of the expedition was to reach the South Pole, and as that object required an advance into the heart of Antarctica, no better route could have been selected. There can be little doubt that the expedition would have been completely successful and reached the Pole but for the accidents to the ponies. Four of them died in the winter quarters, one from eating some poisoned shavings, and three from eating sand-perhaps due to the craving of horses for salt, that may not have been adequately allowed for in their food. The most irreparable accident was the loss of the last pony during the southern sledge journey by its fall into a crevasse on the Beardmore Glacier. The sledge party was thus deprived of an important part of its reserve food, and the accident was especially annoying, as the pony was to have been killed that night. The horse meat was not a complete success, as it brought on dysentery. Sir Ernest Shackleton explains this somewhat unexpected result by the meat being poisoned by a toxin of exhaustion. As the symptoms of fatigue can be transmitted by inoculation from a tired to an untired dog, the suggestion sounds probable.

The work is prefaced by an admirable introduction by Dr. Mill on previous Antarctic work. The first volume describes the equipment, the vain attempt to land on the eastern side of the Great Ice Barrier, the establishment of headquarters on MacMurdo Sound, and the winter's work there. The motor car proved of great service around the station, but though it ran well on smooth sea ice, it would have been of no use on the soft surface of the Barrier.

The great sledge journey to the south was, therefore, dependent upon the ponies; and these did their work well. The sledging party consisted of Sir Ernest Shackleton, Adams, Wild, and Marshall, with

1 " The Heart of the Antarctic. Being the Story of the British Antarctic Expedition, 1907-9." By Sir E. H. Shackleton, C.V.O. With an IntroExpeditson, 1907-9." By Sir E. H. Shackleton, C. V.O. With an Intro-
duction by Dr. Hugh Robert Mill. Vol. i., pp. xlviii $+372 ; 132$ plates. duction by Dr. Hugh Robert Mill. Vol. i., pp. xlviti $372 ; 132$ plates.
Vol. ii., pp. xvi+419; 141 plates, 3 maps. (London: W. Heinemann, I909.) Vol. ii., pp. xvi $+419 ;$
Price, 2 vols., $36 s$. net. 